\title{
JNPH
}

Volume 6 No. 1 (April 2018)

(C) The Author(s) 2018

\section{HUBUNGAN ANTARA PENGALAMAN MEMPEROLEH HUKUMAN FISIK DI MASA ANAK DENGAN PERILAKU AGRESIF PADA REMAJA DI SMKN 02 KOTA BENGKULU}

\section{COORELATION BETWEEN EXPERIENCE GAINING PHYSICAL PUNISHMENT IN CHILDHOOD WITH AGGRESSIVE BEHAVIOR ON TEENS AT SMKN 02 BENGKULU}

\author{
IDA SAMIDAH, MURWATI, DAN MIRAWATI \\ DOSEN FIKES UNIVED BENGKULU
}

\begin{abstract}
ABSTRAK
Pengalaman memperoleh hukuman fisik anak adalah pelecehan fisik dari orang tua fisik yang dapat menyebabkan rasa sakit sebagai risiko atau hasil dari kesalahan seseorang. Pengalaman ini akan mempengaruhi sisi fisik dan psikologis anak yang akan menyebabkan trauma pada anak dan sikap pemodelan perilaku yang diterima oleh anak. Tujuan Penelitian Mengetahui hubungan antara pengalaman mendapatkan hukuman fisik sejak kecil dengan perilaku agresif sebagai remaja di kelas XI di SMKN 2 Kota Bengkulu. Metodologi Penelitian Rancangan penelitian yang digunakan adalah metode deskriptif analitik dengan pendekatan cross sectional yaitu penelitian untuk mempelajari korelasi dinamika antara faktor risiko dengan pengaruh, dengan pendekatan, observasi atau pengumpulan data pada satu waktu (pendekatan titik waktu). Hasil penelitian menunjukkan bahwa $42(46,2 \%)$ siswa memiliki perilaku agresif dan nonagresif dari $36(53,8 \%)$, dimana $54(69,2 \%)$ siswa mengalami pengalaman hukuman fisik sementara $24(30,8 \%)$ Siswa yang tidak mengalami hukuman fisik orang tua mereka. Hasil uji chi-square menunjukkan bahwa Ha diterima, ini ditunjukkan oleh angka yang signifikan (nilai p) $=0,004<\alpha=0,05$. Jadi dapat disimpulkan bahwa, ada hubungan antara pengalaman mendapatkan hukuman fisik di masa kecil dengan perilaku agresif pada remaja di SMK N 02 Kota Bengkulu.
\end{abstract}

Kata kunci: Hukuman fisik dan Perilaku Agresif

\begin{abstract}
The experience of acquiring the child's physical punishment is the physical abuse of a physical parent that can cause pain as a risk or result of a person's wrongdoing. This experience will affect the physical and psychological side of the child that will cause trauma to the child and the attitude of modeling of the behavior received by the child. Research Objectives Known the relationship between experience of obtaining physical punishment since childhood with aggressive behavior as a teenager in class XI in SMKN 2 Kota Bengkulu. Research Methodology The research design which is used is descriptive analytic method with cross sectional approach that is research to study correlation dynamics between risk factors with effect, by approach, observation or data collection at one time (point time approaches).The results showed that $42(46.2 \%)$ students had aggressive and non-aggressive behaviors of 36 $(53.8 \%)$, of which $54(69.2 \%)$ students had experience of corporal punishment while $24(30.8 \%$
\end{abstract}


) Students who did not experience the physical punishment of their parents. The results of the chi-square test show that $\mathrm{Ha}$ is accepted, this is indicated by a significant number ( $\mathrm{p}$ value) $=$ $0.004<\alpha=0.05$. So it can be concluded that, there is a relationship between experience of obtaining physical punishment in childhood with aggressive behavior in adolescents at SMK N 02 Kota Bengkulu.

\section{Keywords: Physical punishment and Aggressive Behavior}

\section{PENDAHULUAN}

Remaja merupakan populasi yang besar dari penduduk dunia. Data demografi menunjukkan bahwa penduduk didunia jumlah populasi remaja merupakan populasi yang besar.

Menurut World Health Organization (WHO) sekitar seperlima dari penduduk dunia dari remaja berumur 10-19 tahun, sekitar 900 juta berada dinegara sedang berkembang. Di asia pasifik jumlah penduduknya merupakan $60 \%$ dari penduduk dunia, seperlimanya adalah remaja umur 1019 tahun.

Di indonesia menurut Biro Pusat Statistik kelompok umur 10-19 tahun adalah $22 \%$, yang terdiri dari 50,9\% remaja laki-laki dan $49,1 \%$ remaja perempuan (Biro Pusat Statistik, 2010).

Penelitian dan pengembangan (LITBANG) juga menunjukan di Jakarta , pada tahun 2010 tercatat 128 kasus tawuran antar pelajar. Angka tersebut meningkat 100\% pada 2011, yakni 330 kasus tawuran yang menewaskan 82 pelajar. Pada bulan januarijuni 2012, telah terjadi 139 tawuran yang menewaskan 82 pelajar. (Lukmansyah \& andini, 2012).

Pengalaman memperoleh hukuman fisik masa anak adalah perlakuan kasar orang tua secara jasmani yang dapat menimbulkan rasa sakit sebagai resiko atau akibat dari kesalahan yang dilakukan seseorang. Pengalaman ini akan berdampak dari segi fisik maupun psikologis anak yang akan menimbulkan trauma pada anak dan sikap modelling dari perilaku yang diterima oleh anak tersebut. Walaupun itu hukuman fisik, ini juga mengakibatkan rasa sakit secara fisik atau jasmani.

\section{TUJUAN PENELITIAN}

Mengetahui hubungan antara pengalaman memperoleh hukuman fisik sejak masa anak dengan perilaku agresif saat remaja dikelas XI di SMKN 2 Kota Bengkulu.

\section{METODE PENELITIAN}

Desain penelitian yang digunakan adalah metode deskriptif analitik dengan pendekatan cross sectional yaitu penelitian untuk mempelajari dinamika korelasi antara faktor-faktor resiko dengan efek, dengan cara pendekatan, observasi atau pengumpulan data sekaligus pada suatu saat (point time apporach). Artinya tipe subjek penelitian hanya diobservasi sekali saja dan pengukuran terhadap status karakter atau variabel subjek pada saat pemeriksaan (Notoadmojo, 2010). Populasi dalam penelitian ini adalah seluruh siswa laki-laki SMK N 02 Bengkulu Kelas XI yaitu sebanyak 351. Sampel pada penelitian ini adalah sebanyak 78 siswa Kelas XI Di SMK N 02 Bengkulu.

\section{HASIL PENELITIAN}

\section{A.Analisis univariat}

\section{Tabel 1. Distribusi Frekuensi Perilaku Agresif}

\begin{tabular}{ccc}
\hline Perilaku Agresif & $\begin{array}{c}\text { Frekuensi } \\
(\mathrm{F})\end{array}$ & $\begin{array}{c}\text { Persentase } \\
(\%)\end{array}$ \\
\hline Tidak Berperilaku Agresif & 37 & 47.4 \\
agresif & 41 & 52.6 \\
\hline Total & 78 & 100 \\
\hline
\end{tabular}

Berdasarkan tabel 1 diatas menunjukan bahwa perilaku yang ditujukan siswa kelas XI 
SMK N 02 Bengkulu di dominasi dengan tidak berperilaku agresif dengan persentase sebesar $(47,4 \%)$ hampir sebagian dari responden ,sedangkan siswa yang berperilaku agresif sebesar $(52,6 \%)$ sebagian besar dari responden.

Tabel 2. Frekuensi Berdasarkan Pengalaman Memperoleh Hukuman Fisik

\begin{tabular}{ccc}
\hline Pengalaman & $\begin{array}{c}\text { Frekuensi } \\
(\mathrm{F})\end{array}$ & $\begin{array}{c}\text { Persentase } \\
(\%)\end{array}$ \\
\hline Tidak Memperoleh & 34 & 43.6 \\
hukuman fisik & 44 & 56.4 \\
memperoleh hukuman fisik & & \\
\hline Total & 78 & 100 \\
\hline
\end{tabular}

Berdasarkan tabel 2 diatas menunjukan bahwa perilaku yang ditujukan siswa kelas XI SMK N 02 Bengkulu di dominasi dengan tidak memperoleh hukuman fisik dengan persentase sebesar $(43,6 \%)$ hampir sebagian dari respoden, sedangkan siswa yang memperoleh hukuman fisik sebesar $(56,4 \%)$ sebagian besar dari responden.

\section{B. Analisis Bivariat}

Tabel 3. Hubungan Antara Pengalaman Memperoleh Hukuman Fisik Di Masa Anak Dengan Perilaku Agresif Pada Remaja

\begin{tabular}{|c|c|c|c|c|c|c|c|}
\hline \multirow{2}{*}{$\begin{array}{l}\text { Pengalaman } \\
\text { Memperoleh } \\
\text { hukuman } \\
\text { fisik }\end{array}$} & \multicolumn{4}{|c|}{ perilaku } & \multirow[b]{2}{*}{ Total } & \multirow[b]{2}{*}{$\%$} & \\
\hline & $\begin{array}{c}\text { Tdk } \\
\text { agresif }\end{array}$ & $\%$ & $\begin{array}{c}\text { Agresi } \\
\mathrm{f}\end{array}$ & $\%$ & & & \\
\hline Memperoleh & 23 & 29.5 & 11 & 14.1 & 34 & 100 & \\
\hline $\begin{array}{c}\text { Tdk } \\
\text { memperoleh }\end{array}$ & 14 & 17.9 & 30 & 38.5 & 44 & 100 & 0,0 \\
\hline Total & 37 & 47,4 & 41 & 69.2 & 78 & 100 & \\
\hline
\end{tabular}

Pada tabel 3 diatas menunjukkan bahwa dari 37 (100\%) Siswa memperoleh hukuman fisik , siswa tidak berperilaku agresif (29.5\%) hampir sebagian dari responden, siswa yang berperilaku agresif (14.1\%) sebagian kecil dari responden.

\section{PEMBAHASAN}

\section{A. Gambaran Pengalaman Memperoleh Hukuman Fisik di Masa Anak Dengan Perilaku Agresif Pada Remaja Di SMKN 02 Kota Bengkulu}

Berdasarkan tabel 1 diatas menunjukan bahwa perilaku yang ditujukan siswa kelas XI SMK N 02 Bengkulu di dominasi dengan tidak berperilaku agresif dengan persentase sebesar (47,4 \%) hampir sebagian dari responden ,sedangkan siswa yang berperilaku agresif sebesar $(52,6 \%)$ sebagian besar dari responden.

Dari hasil kuesioner yang dibagikan kepada responden maka dapat disimpulkan bahwa memberikan hukuman fisik yang dilakukan oleh orang tua terhadap siswa di SMK N 02 Kota Bengkulu masih menerapkan pengalaman yang tidak baik.

Hasil penelitian tersebut sejalan dengan penelitian yang dilakukan oleh Fortuna (2008) salah satu hal yang mempengaruhi terbentuknya perilaku agresif adalah dari pengalaman mendapat hukuman fisik di waktu anak. Jika orang tua dapat mengurangi kebiasaan berperilaku agresif, diharapkan anak-anak juga akan berkurang agresivitasnya. Dari hasil pengamatan ternyata anak banyak meniru dari orang tua yang sedikit-sedikit berteriak, menjerit, marah-marah sampai dengan memukul baik antara suami-istri, dengan tetangga, maupun kepada anak-anak sendiri. Belajar model adalah proses peniruan tingkah laku orang lain yang dilihat, dilakukan secara sadar atau tidak sadar.

\section{B. Gambaran Pengalaman Memperoleh Hukuman Fisik di Masa Anak Dengan Perilaku Agresif Pada Remaja Di SMKN 02 Kota Bengkulu}

Berdasarkan tabel 2 diatas menunjukan bahwa perilaku yang ditujukan siswa kelas XI SMK N 02 Bengkulu di dominasi dengan tidak memperoleh hukuman fisik dengan persentase sebesar $(43,6 \%)$ hampir sebagian 
dari respoden, sedangkan siswa yang memperoleh hukuman fisik sebesar $(56,4 \%)$ sebagian besar dari responden.

Penelitian yang dilakukan oleh ismail (2014) salah satu hal yang mempengaruhi terbentuknya perilaku agresif adalah pengalaman memperoleh hukuman fisik dimasa anak. Menurut Scheinders (2011), mengatakan bahwa agresif merupakan luapan emosi sebagai reaksi terhadap kegagalan individu yang ditampakkan dalam bentuk pengrusakan terhadap orang atau benda dengan unsur kesengajaan yang diekspresikan dengan kata-kata (verbal) dan perilaku non verbal.

Menurut Koeswara (2012) faktor penyebab remaja berperilaku agresif bermacam-macam, sehingga dapat dikelompokkan menjadi faktor sosial, faktor lingkungan,faktor hormon, alkohol,obatobatan (faktor yang berasal dari luar individu) dan sifat kepribadian (faktor-faktor yang berasal dari dalam individu).

Dari beberapa teori dan penelitian diatas dapat ditarik kesimpulan bahwa perilaku agresif pada remaja di SMKN 02 Kota Bengkulu adalah suatu perilaku yang dimaksudkan unutk melukai atau menyakiti yang mengandung unsur kekerasan, serangan atau gangguan baik secara fisik ataupun verbal, dan merusak atau mengambil hak milik orang lain dengan atau tanpa tujuan dan korban tidak menghendaki perilaku tersebut.

\section{Hubungan antara pengalaman memperoleh hukuman fisik dimasa anak dengan perilaku agresif pada remaja di SMKN 02 Kota Bengkulu tahun 2017}

Pada tabel 3 diatas menunjukkan bahwa dari 37 (100\%) Siswa memperoleh hukuman fisik, siswa tidak berperilaku agresif (29.5\%) hampir sebagian dari responden , siswa yang berperilaku agresif (14.1\%) sebagian kecil dari responden.

Dari $41(100 \%)$ siswa yang tidak memperoleh hukuman fisik, siswa yang tidak agresif (17.9\%) sebagian kecil dari responden dan siswa yang agresif (38.5 \%) hampir sebagian dari responden.

Hasil uji chi-square menunjukkan bahwa Ha diterima, hal ini ditunjukkan oleh angka signifikan $(p$ value $)=0,004<\dot{\alpha}=$ 0,005 . Sehingga dapat disimpulkan bahwa, ada hubungan antara pengalaman memperoleh hukuman fisik di masa anak dengan perilaku agresif pada remaja di SMK N 02 Kota Bengkulu.

Masa remaja ialah usia dimana indvidu berintegrasi dengan masyarakat dewasa, usia dimana anak-anak tidak lagi merasa dibawah tingkatan yang sama, sekurang-kurangnya dalam masalah hak. Intergritas dalam masyarakat (dewasa), yang kenyataannya merupakan ciri khas yang umum dari periode perkembangan ini (Hurlock,2011).

Thorndike (Koeswara, 2012) dengan law of effect menekankan bahwa dalam proses belajar atau pembentukan suatu tingkah laku, reward dan punishmnet memainkan peranan penting. Agresi terbentuk dan diulang dilakukan oleh individu karena dengan agresinya itu individu tersebut memperoleh efek atau hasil yang menyenangkan. Adapun apabila dengan agresinya itu individu memperoleh efek yang sebaliknya, yakni efek atau hasil yang tidak menyenangkan, maka agresi itu tidak akan diulang.

Hukuman fisik ini juga mengakibatkan psikologis yang terganggu pada korbannya yang menyebabkan si anak menjadi trauma tersendiri atau malah anak terbentuk suatu sifat atau sikap untuk membalas dendam apabila sudah menginjak remaja. Ini lah akibat dari pengalaman memperoleh hukuman fisik di masa anak.

\section{KESIMPULAN}

Berdasarkan tujuan dan hasil dari penelitian mengenai hubungan antara pengalaman memperoleh hukuman fisik di masa anak dengan perilaku agresif pada remaja di SMKN 02 Kota Bengkulu tahun 2017 maka dapat diambil kesimpulan sebagai berikut : 
1. Sebagian besar dari responden memiliki berperilaku agresif di SMKN 02 Kota Bengkulu

2. Sebagian besar dari responden memperoleh hukuman fisik di SMKN 02 Kota Bengkulu.

3. Ada hubungan antara pengalaman memperoleh hukuman fisik di masa anak dengan perilaku agresif pada remaja di SMKN 02 Kota Bengkulu Tahun 2017.

\section{SARAN}

Berdasarkan hasil kesimpulan penelitian yang dilakukan, maka peneliti menyarankan :

1. Bagi pendidikan

Hasil penelitian diharapkan dapat memberikan informasi bagi mahasiswa STIKes Dehasen Bengkulu untuk perkembangan ilmu keperawatan dan referensi di masa yang akan datang.

\section{Bagi Sekolah}

Sebagai informasi dan masukan bagi guru SMKN 2 Kota Bengkulu, khususnya guru bagian kemahasiswaan dan bimbingan konseling dalam memberikan bimbingan dan penyuluhan pada siswasiswa yang bermasalah.

\section{Bagi Orang Tua}

Secara praktis hasil penelitian ini diharapkan dapat menjadi dasar pertimbangan dan pengetahuan bagi orang tua dan masyarakat untuk menyiapkan kehidupan yang lebih baik bagi remaja dengan cara memberikan gambaran akan pentingnya peranan keluarga terhadap terbentuknya perilaku remaja yang baik.

\section{Bagi Peneliti}

Kegiatan penulisan ini dapat memperluas wawasan peneliti tentang konsep-konsep penelitian dan mengembangkan kemampuan penulis dalam menerapkan ilmu pengetahuan yang didapat diperkuliahan

\section{DAFTAR PUSTAKA}

Anisa Siti Maryanti. 2012. Pengaruh Hukuman Fisik Terhadap Perilaku Agresif Anak Usia 4-5 Tahun. Skripsi. Universitas Negeri Semarang.

Aprilia, K. 2011. Hubungan antara kecerdasan emosional dengan perilaku agresif Pada siswa kelas 2 smk 45 di lembang. Diunduh februari 2017, dari : http:/gunadarmawan.com

Ardi, 2013, Harian Rakyat Bengkulu, Bengkulu: Rakyat Bengkulu. http://www.harianrakyatbengkulu.com. 19 Februari 2017

Bailey, R.H. 2012. Kekerasan dan Agresi. diterjemahkan oleh Wirono S., Jakarta: Tira Pustaka.

Fotuna Fini, 2008. “ Hubungan Pola Asuh Dengan Perilaku Agresif Pada Remaja Di SMKN 1 Jakarta", Jakarta: Universitas Gunadarma.

Fuad Nashori. 2007. Hubungan Komunikasi Remaja dan Orang Tua dengan Agresifitas Remaja. Skripsi. Fakultas Psikologi: Universitas Islam Indonesia

Hockenberry, M.J. 2010, Nursing Care Of Infants And Children, (8th ed.).St.Louis : Mosby Elsevier.

Lazaro. 2011. Gangguan psikologi pada remaja. Diunduh 12 februari 2017, dari : http// gangguan-psikologi-padaremaja-lazaro.co.id

Masykouri, 2005, Perilaku Agresif Remaja, Jakarta : PT. Pustaka Cipta.

Monks, F.J 2010 Psikologi Perkembangan. Yogyakarta: Gajah Mada University Press

Schneinders, A.A 2011. Personality Adjusment And Mental Health. New York: Holt, Rinehart \& Winston.

Setiawan. 2012 pengaruh menonton video kekerasan terhadap perilaku agresif pada anak-anak di SD $N 1$ pasundan, di unduh Februari 2017, dari : http//setiawan.com 